\title{
Sistem Pendukung Keputusan Pemilihan Program Studi menggunakan Metode Analitycal Hierarchy Process (AHP)
}

\author{
Iis Wahyuni ${ }^{1^{*}}$, Arief Hidayat ${ }^{2}$ \\ ${ }^{1,2}$ Jurusan Teknik Informatika, Fakultas Teknik, Universitas Wahid Hasyim \\ Jl. Menoreh Tengah X/22, Sampangan, Semarang 50236. \\ *Email: Iiswahyu776@gmail@gmail.com
}

\begin{abstract}
Abstrak
Pemilihan program studi merupakan salah satu permasalahan yang dihadapi oleh para siswa yang ingin melanjutkan program studi di perguruan tinggi. Banyak siswa yang merasa bingung untuk memilih program studi apa yang cocok untuk minat mereka. Penulis menggunakan metode Analitycal Hierarchy Process (AHP) sebagai metode pemecahan masalah berdasarkan bobot kriteria dalam penelitian ini. Empat kriteria yang digunakan yaitu fasilitas, kualitas, biaya, dan akreditasi. Oleh karena itu penulis membangun sebuah sistem yang dapat membantu proses pemilihan program studi dengan menghasilkan alternatif program studi yang dipilih. Sistem pendukung keputusan pemilihan program studi ini dibuat dengan bahasa pemrograman PHP dan MYSQL sebagai databasenya. Sistem yang dibangun mampu memberikan rekomendasi dari program studi yang diurutkan berdasarkan bobot/skor tertinggi. Hasil penelitian yaitu sebuah sistem yang dapat memberikan alat bantu untuk mengambil keputusan oleh calon mahasiswa dalam memilih program studi yang ingin melanjutkan pendidikan di Universitas Wahid Hasyim (UNWAHAS) khususnya Fakultas Teknik.
\end{abstract}

Kata Kunci: AHP, Program Studi, SPK.

\section{PENDAHULUAN}

\subsection{Latar Belakang}

Dalam Berbagai suatu proses pemilihan program studi melalui hasil perangkingan pada PTN/PTS bagi calon siswa/ calon mahasiswa serta orang tua yang merupakan proses yang begitu rumit apabila hal-hal tersebut dalam pertimbangan yang akan membuat kesalahan dalam pemilihan program studi pada PTN/PTS yang pada akhirnya membuat mereka menyesal dan menyusahkan mereka. Oleh karena itu untuk mendapatkan informasi yang cepat dan hampir akurat maka pemilihan program studi PTN/PTS dibutuhkan suatu otomatisasi teknologi. Maka kebutuhan tersebut dalam sebuah sistem pendukung keputusan pemilihan program studi bagi mahasiswa teknik khususnya pada UNWAHAS (Ali, Untuk model penelitian yang dikembangkan merupakan penelitian sistem pendukung keputusan dengan multi kriteria metode Analitycal Hierarchy Process (AHP). Model penelitian sistem pendukung keputusan ini menggunakan metode Analitycal Hierarchy Process (AHP) sehingga struktur dalam pengambilan keputusan tersebut dapat menyesuaikan metode yang digunakan. Bahwa metode AHP disini dapat menghasilkan keputusan yang relative dan responden.
Responden penelitian meliputi : Siswa SMA dan SMK yang dipilih dalam sampel untuk pendahuluan, Sedangkan program studi di PTN/ PTS tersebut untuk mereview model Analitycal Hierarchy Process (AHP) yang dikembangkan oleh para mahasiswa serta orang tua yang pernah menyekolahkan putra-putrinya ke tingkat perguruan tinggi. Metode Analitycal Hierarchy Process (AHP) tersebut pada hakekatnya adalah suatu teknik untuk pengambilan keputusan yang komprehensif dengan perhitungan pada hal-hal yang bersifat kualitatif dan kuantitatif (Budilaksono dkk, 2016). Oleh karena itu, berdasarkan latar belakang sebelumnya peneliti berusaha merancang sebuah sistem yang dapat memberikan suatu rekomendasi kepada calon mahasiswa dalam memilih program studi pada fakultas teknik UNWAHAS dengan kriteria yang di inginkan calon mahasiswa yang berjudul "Sistem Pendukung Keputusan Pemilihan Program Studi Menggunakan Metode Analitycal Hierarchy Process (AHP).

\section{KAJIAN PUSTAKA}

\subsection{Pengertian Sistem Pendukung Keputusan}

Sistem pendukung keputusan atau yang disebut dengan decision support system (DSS) merupakan sistem informasi interaktif yang 
menyediakan informasi, pemodelan, dan pemanipulasian data. Sistem ini digunakan untuk membantu pengambilan keputusan dalam situasi yang semiterstruktur dan situasi yang tidak terstruktur, DSS biasanya dibangun untuk mendukung solusi atas suatu masalah untuk mengevaluasi suatu peluang. Aplikasi DSS digunakan dalam pengambilan keputusan. Aplikasi DSS menggunakan CIBS (Computer Based Information System) yang fleksibel, interaktif dan dapat diadaptasi, dikembangkan untuk mendukung solusi atas masalah manajemen spesifik yang tidak terstruktur. DSS ditujukan untuk mendukung manajemen dalam melakukan pekerjaan yang bersifat analitis dalam situasi yang kurang terstruktur dan dengan kriteria yang kurang jelas. DSS tersebut dimaksudkan untuk mengotomatisasikan pengambilan keputusan, yang diberikan perangkat interaktif yang memungkinkan pengambilan keputusan untuk melakukan berbagai analisis menggunakan model-model yang tersedia (Kusrini, 2007).

Tahap-tahap proses dalam Sistem Pendukung Keputusan sebagai berikut ( Na'am, 2017):

1. Penelusuran (Inteligence), yaitu proses dari penelusuran dan pendeteksian elemen-elemen penyebab masalah yang terjadi.

2. Desain (Desain), yaitu merancang beberapa metode yang dapat meneyelesaikan masalah.

3. Pemilihan (choice) yaitu, pemilihan salah satu aternatif desain yang dapat menyelesaikan masalah tersebut.

4. Penerapan (Implementation) yaitu, metode yang menerapkan yang dipilih dalam suatu sistem yang menggunakan alat komputer sebagai alat baru.

Tujuan DSS sebagai berikut (Kusrini, 2007):

1. Membantu manajer dalam pengambilan keputusan atas masalah semitersruktur

2. Memberikan dukungan atas pertimbangan manajer

3. Meningkatkan efektivitas keputusan yang diambil

4. Kecepatan komputasi

5. Peningkatan produktivitas

6. Dukungan kualitas

7. Berdaya saing

Mengatasi keterbatasan kognitif dalam pemprosesan dan penyimpanan pemikiran pengambilan keputusan.

\subsection{Komponen-komponen Sistem Pendukung Keputusan}

Komponen sistem pendukung keputusan terdiri dari beberapa komponen diantaranya (Darmanto dkk, 2014).

\section{Data Management (Manajemen Data)}

Data management merupakan sistem pendukung keputusan yang sebagai penyedia data bagi sistem, yang dimana data disimpan dalam database management system (DBMS), .

2. Model Management (Manajemen Model)

Model management merupakan sistem pendukung keputusan yang mengelola berbagai model yang dibutuhkan dalam melakukan analisis terhadap informasi yang disediakan oleh sistem.

3. Communication (dialog subsistem)

Communication merupakan sistem pendukung keputusan yang user dapat berkomunikasi dan memberikan perintah pada sistem pendukung keputusan melalui subsistem.
4. Knowledge

Pengetahuan)

Knowledge Management merupakan sistem pendukung keputusan subsistem optional yang dapat mendukung subsistem lain yang bertindak sebagai komponen berdiri sendiri.

\subsection{Metode Analytical Hierarchy Process (AHP) \\ Metode yang digunakan adalah metode} Analitycal Hierarki Proses (AHP) merupakan sebuah kerangka dalam mengambil keputusan dengan efektif atas persoalan yang kompleks dengan menyederhanakan atau mempercepat proses pengambilan keputusan dengan memecahkan persoalan-persoalan tersebut dalam bagian-bagiannya, menata bagian atau variabel ini memberi nilai numerik pada pertimbangan subjektif tentang pentingnya tiap variabel dan mensintesis berbagai pertimbangan untuk menetapkan variabel yang mana memiliki prioritas paling tinggi dan bertindak untuk mempengaruhi hasil pada situasi tersebut. (Saaty, 2008). 
Tabel 1. Skala Matriks Perbandingan Berpasangan

\begin{tabular}{|c|c|c|}
\hline $\begin{array}{c}\text { Intensitas } \\
\text { Kepentingan }\end{array}$ & Definisi & Keterangan \\
\hline 1 & $\begin{array}{l}\text { Sama } \\
\text { Pentingnya }\end{array}$ & $\begin{array}{l}\text { Kedua elemen } \\
\text { sama } \\
\text { pentingnya. }\end{array}$ \\
\hline 3 & $\begin{array}{l}\text { Agak lebih } \\
\text { penting } \\
\text { yang satu } \\
\text { atas lainnya }\end{array}$ & $\begin{array}{l}\text { Pengalaman dan } \\
\text { penilaian sangat } \\
\text { memihak satu } \\
\text { elemen } \\
\text { dibandingkan } \\
\text { dengan } \\
\text { pasangannya. }\end{array}$ \\
\hline 5 & $\begin{array}{l}\text { Cukup } \\
\text { penting }\end{array}$ & $\begin{array}{l}\text { Pengalaman dan } \\
\text { keputusan } \\
\text { menunjukkan } \\
\text { kesukaan atas } \\
\text { satu aktivitas } \\
\text { lebih dari yang } \\
\text { lain. }\end{array}$ \\
\hline 7 & $\begin{array}{l}\text { Sangat } \\
\text { penting }\end{array}$ & $\begin{array}{l}\text { Pengalaman dan } \\
\text { keputusan } \\
\text { menunjukkan } \\
\text { kesukaan yang } \\
\text { kuat atas satu } \\
\text { aktivitas lebih } \\
\text { dari yang lain. }\end{array}$ \\
\hline 9 & $\begin{array}{l}\text { Mutlak } \\
\text { lebih } \\
\text { penting }\end{array}$ & $\begin{array}{l}\text { Satu elemen } \\
\text { mutlak lebih } \\
\text { disukai } \\
\text { dibandingkan } \\
\text { dengan } \\
\text { pasangannya, } \\
\text { pada tingkat } \\
\text { keyakinan } \\
\text { tertinggi. }\end{array}$ \\
\hline $2,4,6,8$ & $\begin{array}{l}\text { Nilai tengah } \\
\text { diantara dua } \\
\text { nilai } \\
\text { berdekatan }\end{array}$ & $\begin{array}{l}\text { Bila kompromi } \\
\text { yang } \\
\text { dibutuhkan. }\end{array}$ \\
\hline Kebalikan & - & $\begin{array}{l}\text { Jika aktivitas i } \\
\text { mendapat satu } \\
\text { angka } \\
\text { dibandingkan } \\
\text { dengan aktivitas } \\
\text { i, maka i } \\
\text { memiliki nilai } \\
\text { kebalikannya } \\
\text { dibandingkan } \\
\text { dengan i. }\end{array}$ \\
\hline
\end{tabular}

\subsection{Prinsip Dasar Analytical Hierarchy Process (AHP)}

Dalam menyelesaikan permasalahan dengan (Analytical hierarchy process) AHP ada beberapa prinsip yang harus dipahami diantaranya (Kusrini, 2007:133)

a. Decomposition (Membuat Hierarki)

Dalam menyusun elemen secara hierarki, dan menggabungkan atau mensintesisnya.

Bentuk dalam struktur hirarki decomposition sebagai berikut.

Seperti gambar 1 menjelaskan tentang struktur hirarki AHP.

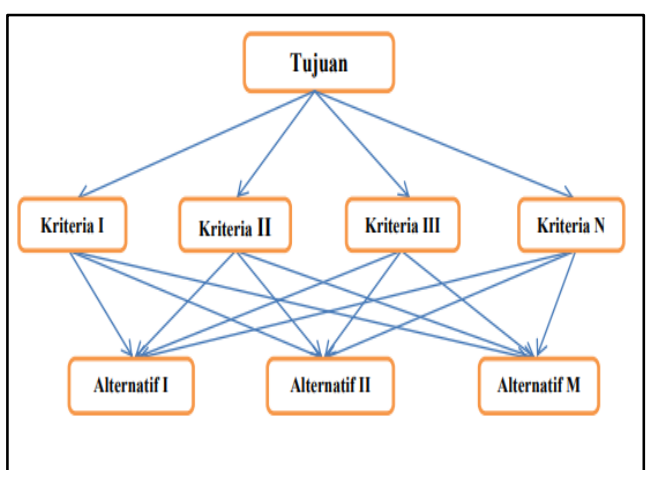

Gambar 1. Struktur Hirarki AHP

b. Comparative Judgment (Penilaian kriteria dan alternatif)

Kriteria dan alternatif dilakukan dengan perbandingan berpasangan menurut Saaty (1988), untuk berbagai persoalan, skala 1 sampai 9 adalah skala terbaik untuk mengekspresikan pendapat.

c. Synthesis of Priority ( menentukan prioritas)

Untuk setiap kriteria dan alternatif, perlu dilakukan perbandingan berpasangan (pairwise Comparisons).

d. Logical Consistency (Konsistensi Logis)

Konsistensi memiliki dua makna. Pertama, objek-objek yang serupa bisa dikelompokkan sesuai dengan keseragaman dan relevansi.

\subsection{Metode Prototype}

Pemodelan prototype didefinisikan sebagai alat yang memberikan ide bagi pembuat maupun pemakai potensial tentang cara system yang berfungsi dalam bentuk lengkapnya, dan proses untuk menghasilkan sebuah prototype disebut prototyping. Adapun tahap-tahap Pengembang sistem yang digunakan yang dijelaskan pada Gambar 2. 


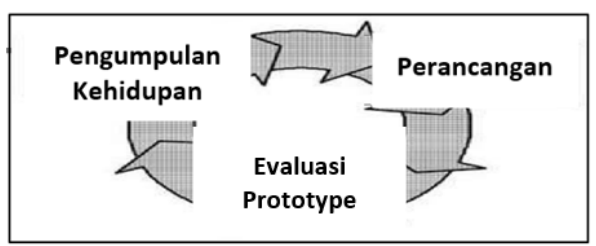

Gambar 2. Metode Prototype

\section{METODE PENELITIAN}

\subsection{Metode Pengumpulan Data}

Pada penelitian ini, dalam pengumpulan data itu sendiri adalah faktor terpenting yang harus dipenuhi untuk dianalisi dan diolah. Pengumpulan data tersebut bertujuan untuk memperoleh informasi yang dibutuhkan untuk menyelesaikan penelitian. Pengumpulan data itu sendiri dilakukan dengan beberapa tahap yang akan dijelaskan dibawah ini:

\section{a. Wawancara}

Pengambilan data disini berupa wawancara atau interview yang dilakukan antara dua komunika yang berbeda antara penulis dengan mahasiswa secara langsung dengan cara mendapatkan informasi-informasi yang dibutuhkan dalam menganalisa dan mengambil suatu kesimpulan dari data yang diambil berdasarkan suatu informasi berupa kriteria seperti fasilitas, kualitas, biaya dan akreditasi sehingga mahasiswa memilih program studi sesuai apa yang mereka inginkan.

\section{b. Studi Pustaka}

Pada tahap studi pustaka ini penulis melakukan pengumpulan data dengan mencari beberapa referensi yang diperoleh dengan literatur atau buku-buku media online dan skripsi mengenai bagian-bagian penting pada penelitian ini.

\section{c. Jenis Data \\ 1. Data Primer}

Yaitu data yang didapatkan secara langsung dari objek penelitian melalui wawancara yang berhubungan dengan informasi yang ada di universitas wahid hasyim semarang.

\section{Data Sekunder}

Yaitu data yang didapatkan oleh penulis baik dari media cetak ataupun buku yang bersifat informasi baik berupa kutipan, literatur buku, makalah seminar dan jurnal penelitian yang berhubungandengan penelitian yang dibuat.

\section{ANALISIS DAN PERANCANGAN}

\subsection{Analisa Sistem}

Analisis sistem digunakan untuk menguraikan suatu sistem pendukung keputusan ke beberapa bagian dalam melakukan identifikasi dan evaluasi pada beberapa masalah, sehingga sistem diusulkan dapat lebih baik.

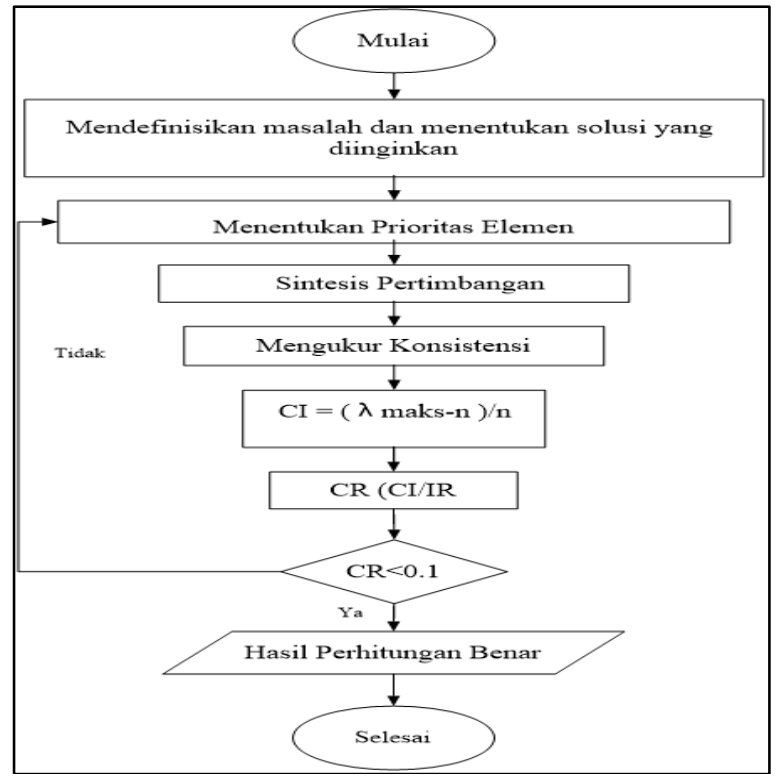

Gambar 3. Flowchart Prosedur Metode

\subsubsection{Menentukan Prioritas Kriteria}

1. Membuat Matriks Perbandingan Berpasangan

2. Membuat Matriks Nilai Kriteria

Matriks ini diperoleh dari rumus sebagai berikut :

Nilai baris kolom baru $=$ Nilai baris kolom lama/jumlah masing-masing kolom lama. Maka Hasil Perhitungan bisa dapat dilihat dalam Tabel IV.2

\begin{tabular}{|c|c|c|c|c|c|}
\hline \multicolumn{7}{|c|}{ Tabel IV. 2 Matriks Nilai Kriteria } \\
\hline Kriteria & Fasilitas & Kualitas & Biaya & Akreditasi & Rata-rata \\
\hline Fasilitas & 0,46153846 & 0,64285714 & 0,4090909 & 0,22222222 & 0,43392718 \\
\hline Kualitas & 0,15384615 & 0,21428571 & 0,4090909 & 0,333333333 & 0,27763902 \\
\hline Biaya & 0,15384615 & 0,07142857 & 0,1363636 & 0,33333333 & 0,17374292 \\
\hline Akreditasi & 0,23076923 & 0,07142857 & 0,0454545 & 0,11111111 & 0,11469086 \\
\hline
\end{tabular}

3. Membuat Matriks Perbandingan Berpasangan Alternatif

Terlebih dahulu kita melakukan penilaian perbandingan berpasangan dari alternatif yang ditentukan oleh penilaian yaitu dari data 
mahasiswa yang ada dengan mengamati skala penilaian kebijakan dari Tabel IV.3 yaitu :

\begin{tabular}{|c|c|c|c|}
\hline \multicolumn{4}{|c|}{ Tabel IV. 3 Matriks Perbandingan Berpasangan Alternatif (Fasilitas) } \\
\hline \multicolumn{4}{|c|}{ Fasilitas } \\
\hline Alternatif & Teknik Mesin & Teknik Kimia & Teknik Informatika \\
\hline Teknik mesin & 1 & 5 & 3 \\
\hline Teknik kimia & 0,2 & 1 & 2 \\
\hline Teknik Informatika & 0,3333333333 & 0,5 & 1 \\
\hline jumlah & 1,533333333 & 6,5 & 6 \\
\hline
\end{tabular}

Teknik mesin $=1$, Teknik Kimia $=5$, Teknik Informatika $=3$;

\section{Membuat Matriks Nilai Alternatif}

Matriks ini diperoleh dari rumus sebagai berikut:

Nilai baris kolom baru $=$ Nilai baris kolom lama / jumlah masing-masing kolom lama.

Maka hasil perhitungan dapat dilihat dalam Tabel IV.4

\begin{tabular}{|c|c|c|c|c|}
\hline \multicolumn{5}{|c|}{ Tabel IV. 4 Matriks Nilai Alternatif(Fasilitas) } \\
\hline \multicolumn{5}{|c|}{ Fasilitas } \\
\hline Alternatif & Teknik mesin & Teknik kimia & $\begin{array}{c}\text { Teknik } \\
\text { Informatika }\end{array}$ & Rata-rata \\
\hline Teknik mesin & 0,652173913 & 0,769230769 & 0,5 & 0,640468227 \\
\hline Teknik Kimia & 0,130434783 & 0,153846154 & 0,333333333 & 0,205871423 \\
\hline $\begin{array}{c}\text { Teknik } \\
\text { informatika }\end{array}$ & 0,217391304 & 0,076923077 & 0,166666667 & 0,153660349 \\
\hline
\end{tabular}

5. Membuat Matriks Perbandingan Berpasangan Alternatif

Terlebih dahulu kita melakukan penilaian perbandingan berpasangan dari alternatif yang ditentukan oleh penilaian yaitu dari data mahasiswa yang ada dengan mengamati skala penilaian kebijakan dari Tabel IV. 5 yaitu :

\begin{tabular}{|c|c|c|c|}
\hline \multicolumn{5}{|c|}{ Tabel IV. 5 Matriks Perbandingan Berpasangan Alternatif (Kualitas) } \\
\hline \multicolumn{5}{|c|}{ Kualitas } \\
\hline Alternatif & Teknik Mesin & Teknik Kimia & Teknik Informatika \\
\hline Teknik mesin & 1 & 3 & 2 \\
\hline Teknik kimia & 0,333333333 & 1 & 4 \\
\hline Teknik Informatika & 0,5 & 0,25 & 1 \\
\hline Jumlah & 1,833333333 & 4,25 & 7 \\
\hline
\end{tabular}

Teknik mesin $=1$, Teknik Kimia $=3$, Teknik Informatika $=2$;
6. Membuat Matriks Nilai Alternatif berikut:

Matriks ini diperoleh dari rumus sebagai

Nilai baris kolom baru $=$ Nilai baris kolom lama/jumlah masing-masing kolom lama. Maka hasil perhitungan dapat dilihat dalam Tabel IV.6

\begin{tabular}{|c|c|c|c|c||}
\hline \multicolumn{5}{|c|}{ Tabel IV. 6 Matriks Nilai Alternatif } \\
\hline \multicolumn{5}{|c|}{ Kualitas } \\
\hline Alternatif & Teknik mesin & Teknik kimia & $\begin{array}{c}\text { Teknik } \\
\text { Informatika }\end{array}$ & Rata-rata \\
\hline Teknik mesin & 0,545454545 & 0,705882353 & 0,285714286 & 0,512350395 \\
\hline Teknik Kimia & 0,181818182 & 0,235294118 & 0,571428571 & 0,329513624 \\
\hline $\begin{array}{c}\text { Teknik } \\
\text { informatika }\end{array}$ & 0,272727273 & 0,058823529 & 0,142857143 & 0,158135982 \\
\hline
\end{tabular}

7. Membuat Matriks Perbandingan Berpasangan Alternatif

Terlebih dahulu kita melakukan penilaian perbandingan berpasangan dari alternatif yang ditentukan oleh penilaian yaitu dari data mahasiswa yang ada dengan mengamati skala penilaian kebijakan dari Tabel IV.7 yaitu : Teknik mesin $=1$, Teknik Kimia $=3$, Teknik Informatika $=4$;

\begin{tabular}{|c|c|c|c|}
\hline \multicolumn{4}{|c|}{ Tabel IV. 7 Matriks Perbandingan Berpasnagan (Biaya) } \\
\hline \multicolumn{4}{|c|}{ Biaya } \\
\hline Alternatif & Teknik Mesin & Teknik Kimia & Teknik Informatika \\
\hline Teknik mesin & 1 & 3 & 4 \\
\hline Teknik kimia & 0,333333333 & 1 & 2 \\
\hline Teknik Informatika & 0,25 & 0,5 & 1 \\
\hline jumlah & 1,583333333 & 4,5 & 7 \\
\hline
\end{tabular}

\section{Membuat Matriks Nilai Alternatif}

Matriks ini diperoleh dari rumus sebagai berikut: Nilai baris kolom baru = Nilai baris kolom lama/jumlah masing-masing kolom lama. Maka hasil perhitungan dapat dilihat dalam Tabel IV.8

\begin{tabular}{|c|c|c|c|c|}
\hline \multicolumn{5}{|c|}{ Tabel IV. 8 Matriks Nilai Alternatif } \\
\hline \multicolumn{5}{|c|}{ Biaya } \\
\hline Alternatif & Teknik Mesin & Teknik Kimia & $\begin{array}{c}\text { Teknik } \\
\text { Informatika }\end{array}$ & Rata-rata \\
\hline Teknik mesin & 0,631578947 & 0,666666667 & 0,571428571 & 0,623224728 \\
\hline $\begin{array}{c}\text { Teknik Kimia } \\
\text { Teknik } \\
\text { informatika }\end{array}$ & 0,210526316 & 0,222222222 & 0,285714286 & 0,239487608 \\
\hline
\end{tabular}


9. Membuat Matriks Perbandingan Berpasangan Alternatif

Terlebih dahulu kita melakukan penilaian perbandingan berpasangan dari alternatif yang ditentukan oleh penilaian yaitu dari data mahasiswa yang ada dengan mengamati skala penilaian kebijakan dari Tabel IV.9 yaitu : Teknik mesin $=1$, Teknik Kimia $=4$, Teknik Informatika $=5$;

\begin{tabular}{|c|c|c|c|}
\hline \multicolumn{4}{|c|}{ Tabel IV. 9 Matriks Perbandingan Berpasangan (Akreditasi) } \\
\hline \multicolumn{4}{|c|}{ Akreditasi } \\
\hline Alternatif & Teknik Mesin & Teknik Kimia & Teknik Informatika \\
\hline Teknik mesin & 1 & 4 & 5 \\
\hline Teknik kimia & 0,25 & 1 & 3 \\
\hline Teknik Informatika & 0,2 & 0,333333333 & 1 \\
\hline Jumlah & 1,45 & 5,333333333 & 9 \\
\hline
\end{tabular}

10.Membuat Matriks Nilai Alternatif berikut:

Matriks ini diperoleh dari rumus sebagai

Nilai baris kolom baru = Nilai baris kolom lama/jumlah masing-masing kolom lama.

Maka hasil perhitungan dapat dilihat dalam Tabel IV.10

\begin{tabular}{|c|c|c|c|c|}
\hline \multicolumn{5}{|c|}{ Tabel IV. 10 Matriks Nilai Alternatif } \\
\hline \multicolumn{5}{|c|}{ Alternatif Akreditasi } \\
\hline Alternatif & Teknik mesin & Teknik kimia & $\begin{array}{c}\text { Teknik } \\
\text { Informatika }\end{array}$ & Rata-rata \\
\hline Teknik mesin & 0,689655172 & 0,75 & 0,5555555556 & 0,665070243 \\
\hline Teknik Kimia & 0,172413793 & 0,1875 & 0,333333333 & 0,231082375 \\
\hline $\begin{array}{c}\text { Teknik } \\
\text { informatika }\end{array}$ & 0,137931034 & 0,0625 & 0,111111111 & 0,103847382 \\
\hline
\end{tabular}

11.Menentukan Data Rangking

\begin{tabular}{|c|c|c|c|c|}
\hline \multicolumn{5}{|c|}{ Tabel IV. 11 Menentukan Data Rangking } \\
\hline \multicolumn{5}{|c|}{ Data Rangking } \\
\hline Alternatif & Fasilitas & Kualitas & Biaya & Akreditasi \\
\hline Teknik Mesin & 0,640468227 & 0,512350395 & 0,623224728 & 0,665070243 \\
\hline Teknik Kimia & 0,205871423 & 0,329513624 & 0,239487608 & 0,231082375 \\
\hline $\begin{array}{c}\text { Teknik } \\
\text { Informatika }\end{array}$ & 0,153660349 & 0,158135982 & 0,137287664 & 0,103847382 \\
\hline
\end{tabular}

12.Hasil Perangkingan

\begin{tabular}{|c|c|c|c|c|}
\hline \multicolumn{5}{|c|}{ Tabel IV. 12 Hasil Perangkingan } \\
\hline \multicolumn{5}{|c|}{ Hasil Perangkingan } \\
\hline Alternatif & Fasilitas & Kualitas & Biaya & Akreditasi \\
\hline Teknik Mesin & 0,277916574 & 0,142248465 & 0,108280886 & 0,076277481 \\
\hline Teknik Kimia & 0,089333207 & 0,091485842 & 0,041609277 & 0,026503037 \\
\hline $\begin{array}{c}\text { Teknik } \\
\text { Informatika }\end{array}$ & 0,066677403 & 0,04390472 & 0,02385276 & 0,011910346 \\
\hline
\end{tabular}

\section{HASIL DAN PEMBAHASAN}

\subsection{Halaman Menu Login Admin}

Gambar 4. menjelaskan tentang halaman yang merupakan halaman menu login untuk admin dalam mengolah sebuah informasi.

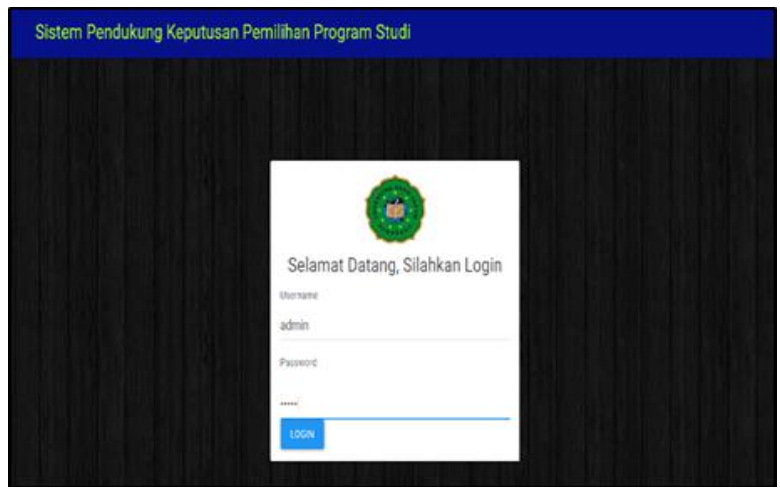

Gambar 4. Halaman Menu Login Admin

\subsection{Halaman Dasboard / Petunjuk \\ Penggunaan}

Gambar 5 menjelaskan tentang halaman yang bagaimana cara menggunakan sistem tersebut berisi halaman home, nilai, data kriteria, data alternatif, data analisa kriteria, data analisa alternatif, rangking dan laporan.

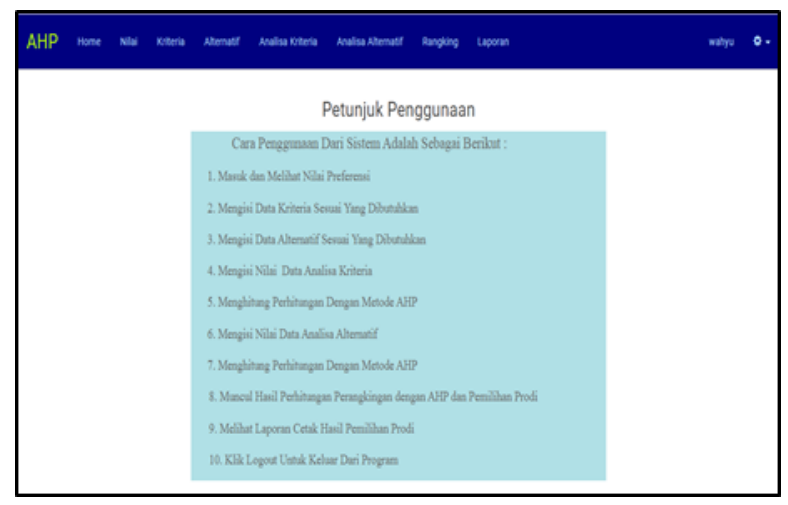

Gambar 5. Halaman Dasboard/Petunjuk Penggunaa

\subsection{Halaman Nilai Preferensi}

Gambar 6 menampilkan Halaman nilai untuk menentukan penilaian data kriteria dan data alternatif untuk perhitungan perbandingan berpasangan. 


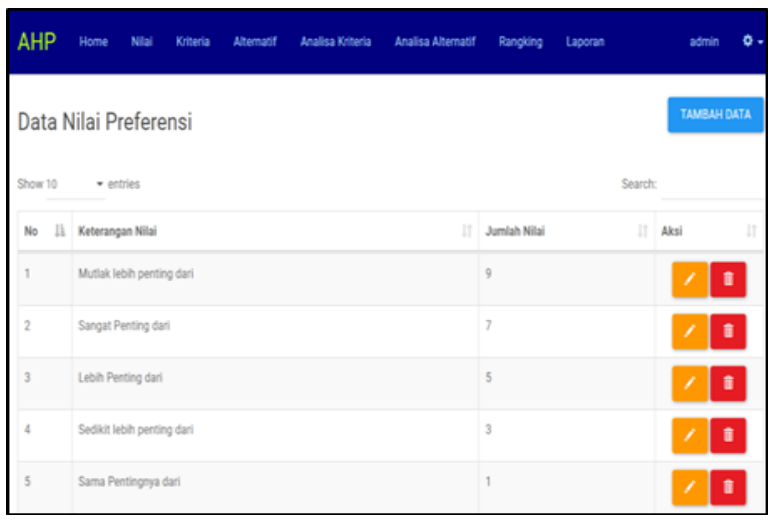

Gambar 6. Halaman Nilai Preferensi

Lanjutan dari gambar 6 untuk penilaian menentukan penilaian data kriteria dan data alternatif untuk perhitungan perbandingan berpasangan.

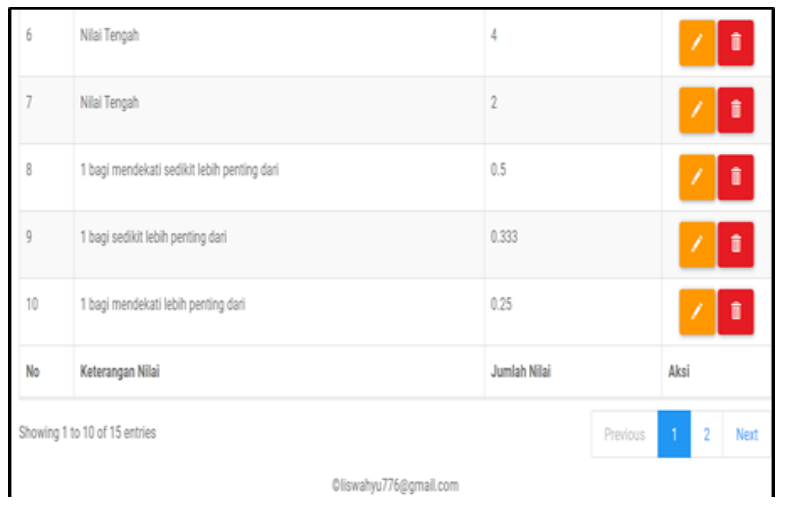

Gambar 7. Halaman Nilai Preferensi Lanjutan

\subsection{Halaman Data Kriteria}

Gambar 8 menjelaskan tentang input data kriteria untuk perhitungan perbandingan berpasangan dalam pemilihan program studi.

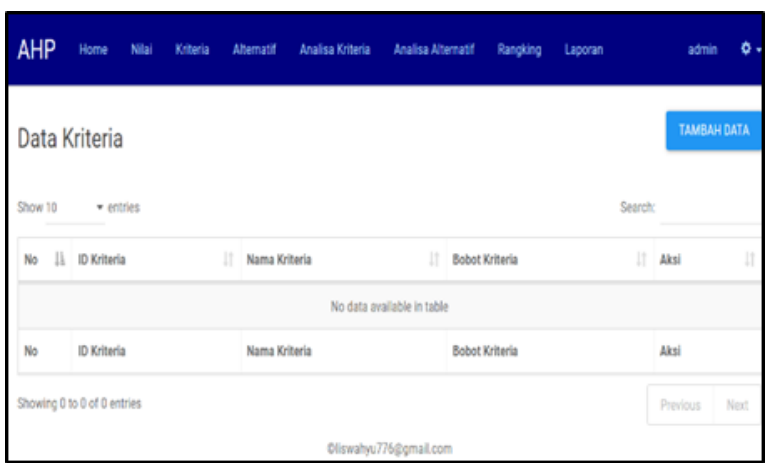

Gambar 8. Halaman Data Kriteria
Lanjutan dari halaman data kriteria, sebelumnya ketika memasuki data kriteria terlebih dahulu menambah kriteria, dengan meliputi id kriteria, nama kriteria, bobot kriteria.

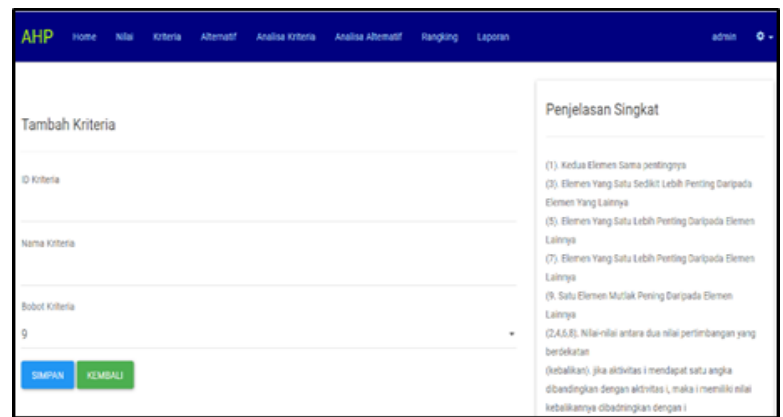

Gambar 9. Halaman Tambah Kriteria

Setelah itu akan muncul data kriteria yang sudah diinput.

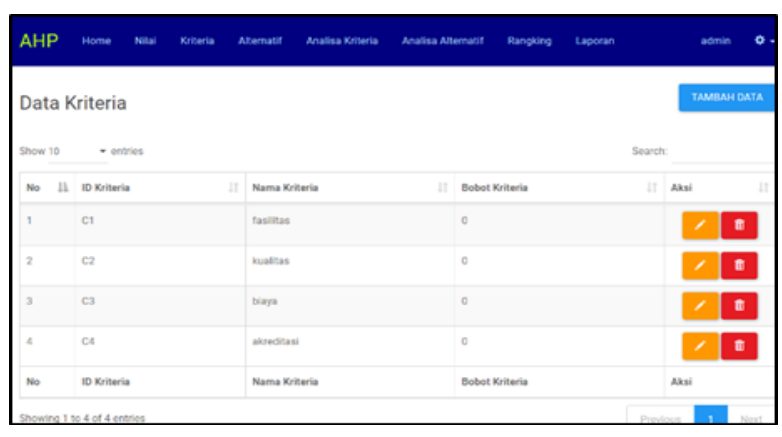

Gambar 10. Halaman Hasil Input Kriteria

\subsection{Halaman Data Alternatif}

Gambar 11 menjelaskan tentang input data alternatif untuk perhitungan perbandingan berpasangan dalam pemilihan program studi.

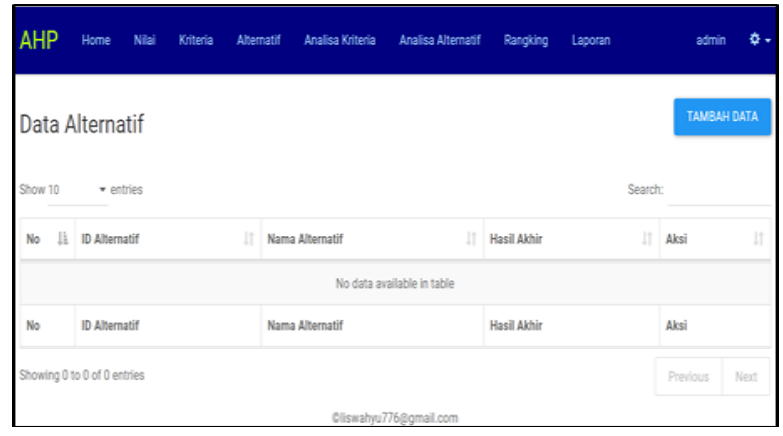

Gambar 11. Halaman Data Alternatif

Lanjutan dari halaman data alternatif, sebelumnya ketika memasuki data alternatif maka menambah data alternatif terlebih dahulu, 
dengan meliputi id alternatif, nama alternatif, bobot alternatif.

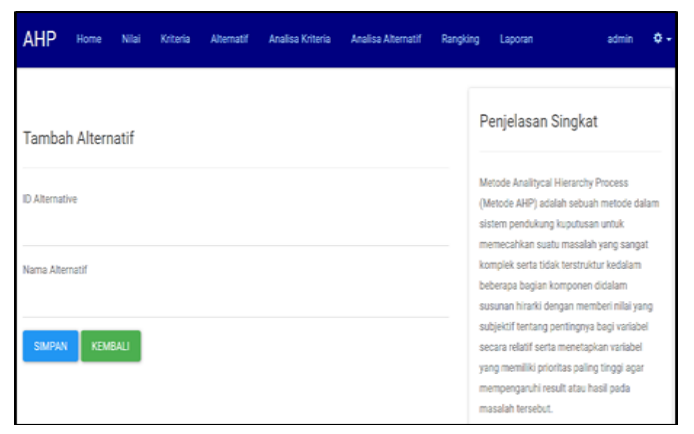

Gambar 12. Halaman Tambah Alternatif

Setelah itu akan muncul alternatif yang sudah diinput.

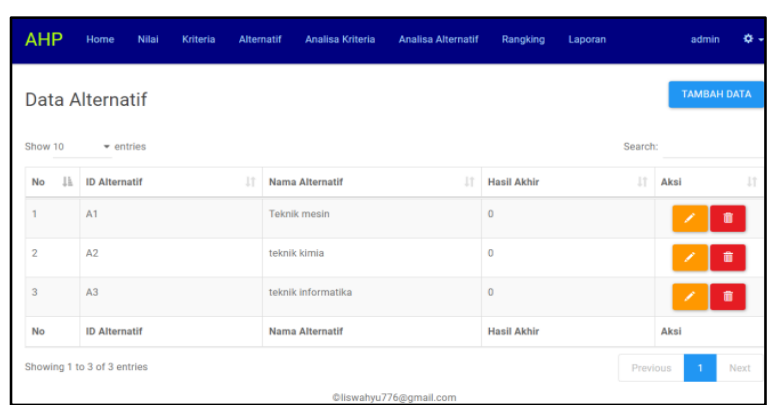

Gambar 13. Halaman Hasil Input Data Alternatif

\subsection{Halaman Analisa Kriteria}

Gambar 14 menjelaskan tentang halaman untuk menentukan nilai perbandingan berpasangan data kriteria yang berupa perbandingan berpasangan fasilitas, kualitas, biaya, dan akreditasi.

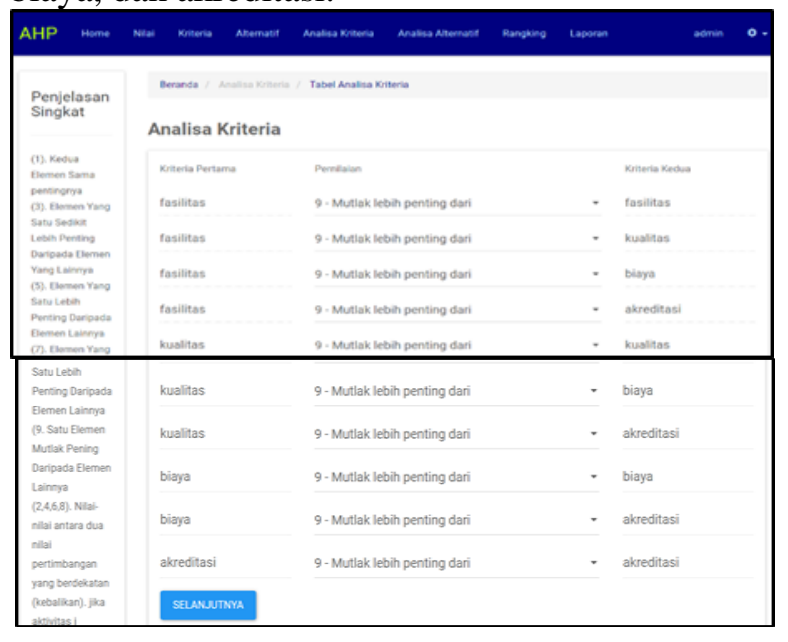

Gambar 14. Halaman Analisa Kriteria
Selanjutnya akan muncul dari menampilkan hasil perhitungan perbandingan berpasangan kriteria fasilitas, kualitas, biaya dan akreditasi

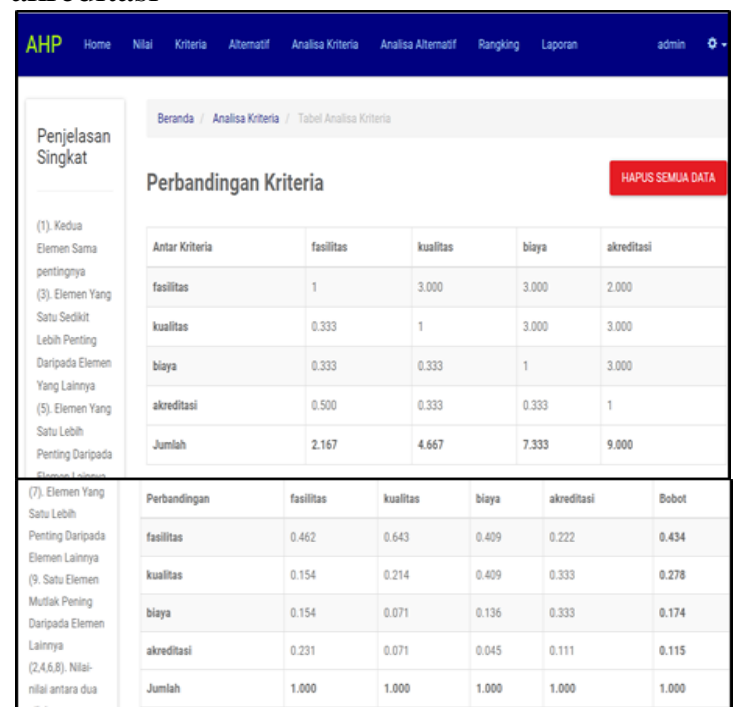

Gambar 15. Halaman Perbandingan Berpasangan

\subsection{Halaman Analisa Alternatif (Fasilitas)}

Gambar 16 menjelaskan tentang analisa data alternatif untuk mengetahui hasil perhitungan perbandingan berpasangan dari setiap proses perhitungan kriteria fasilitas dan alternatif.

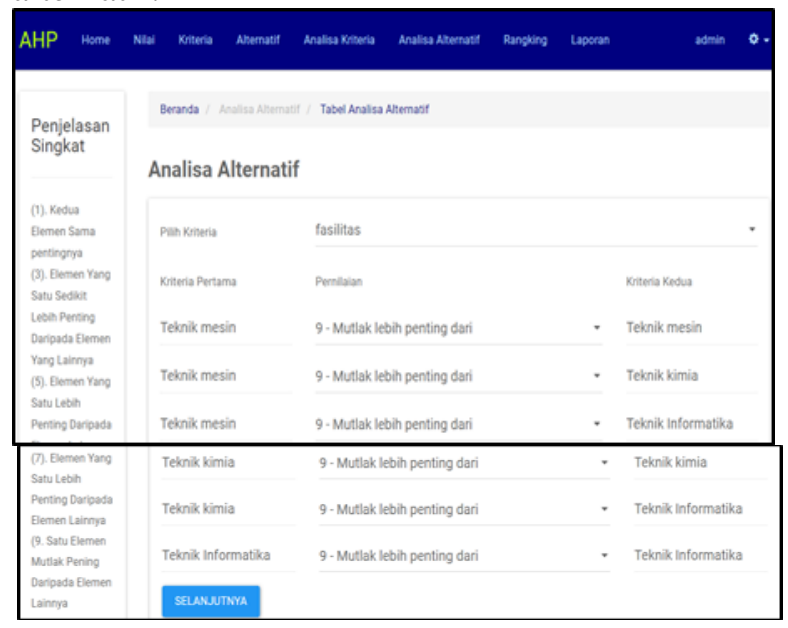

Gambar 16. Halaman Analisa Alternatif (Fasilitas)

Selanjutnya akan menginput nilai yang sesuai dengan kebutuhan perhitungan. 


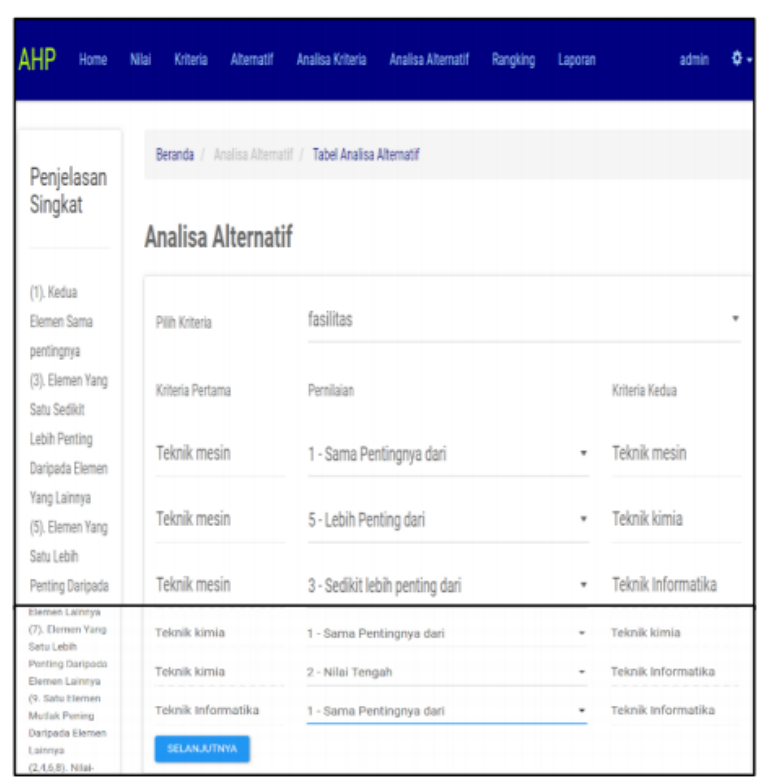

Gambar 17. Halaman Analisa Alternatif

Kemudian akan muncul hasil perhitungan perbandingan berpasangan sesuai dengan alternatif menurut kriteria.

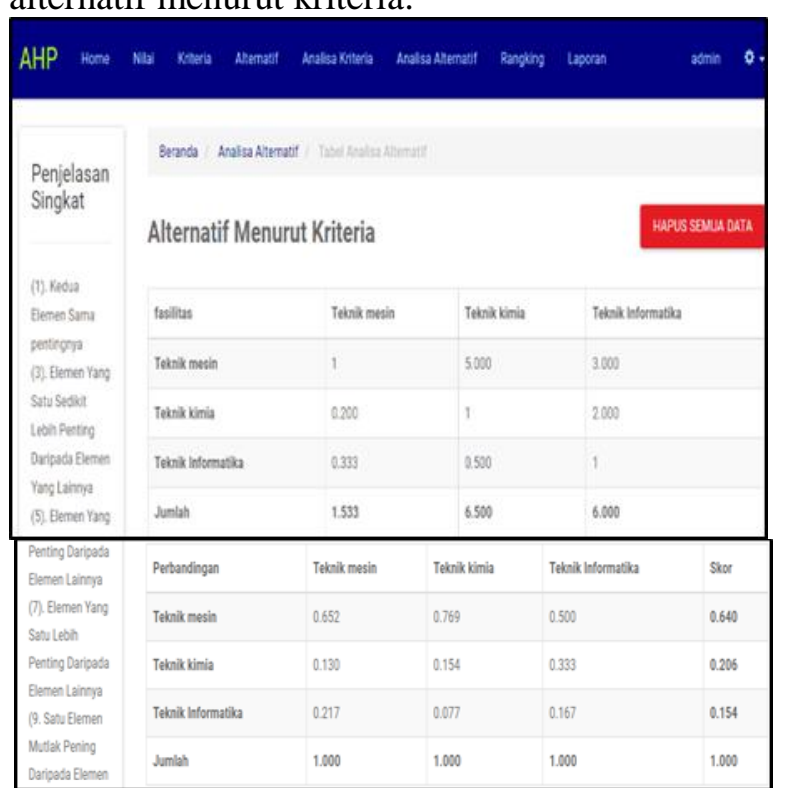

Gambar 18. Halaman Perbandingan Berpasangan Alternatif Menurut Kriteria

\subsection{Halaman Analisa Alternatif (Kualitas)}

Gambar 19 menjelaskan tentang analisa data alternatif untuk mengetahui hasil perhitungan perbandingan berpasangan dari setiap proses perhitungan kriteria kualitas dan alternatif.

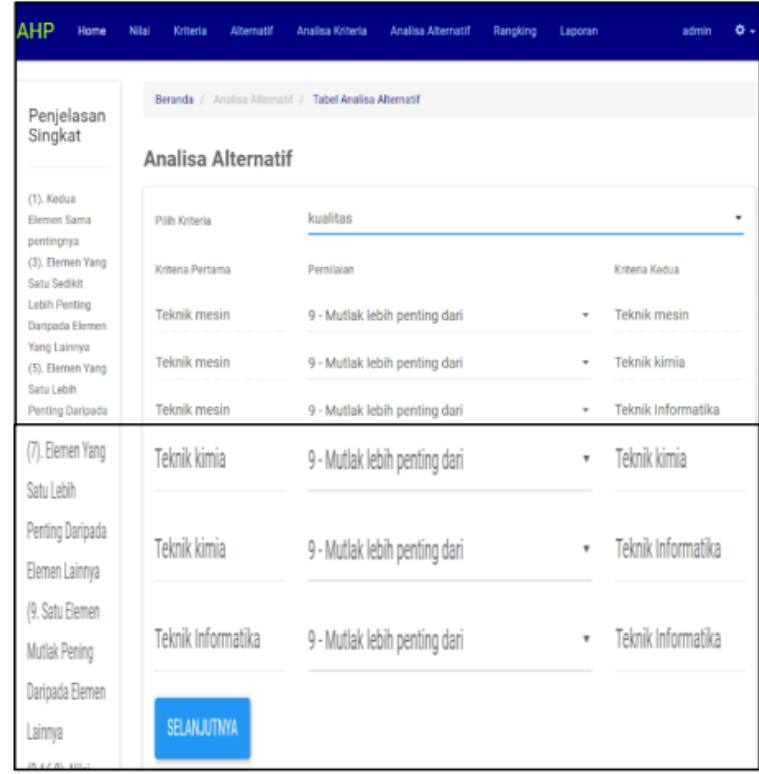

Gambar 19. Halaman Analisa Alternatif (Kualitas)

Selanjutnya akan menginput nilai yang sesuai dengan kebutuhan perhitungan.

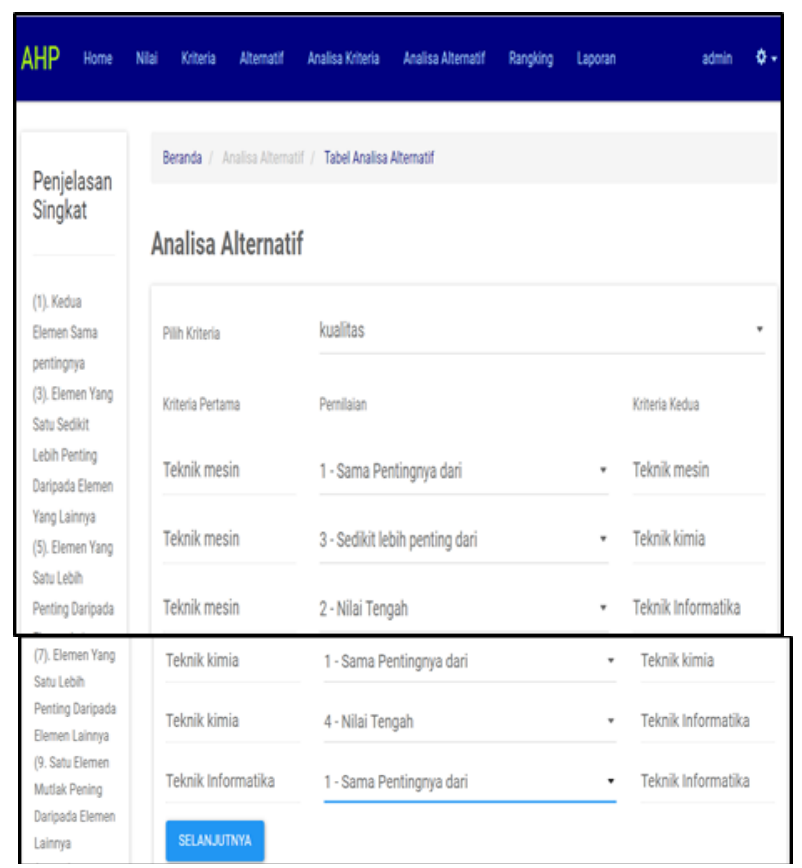

Gambar 20. Halaman Analisa Alternatif Kualitas Lanjutan

Maka selanjutnya akan muncul hasil perhitungan perbandingan berpasangan dalam menentunkan hasil perangkingan progam studi. 


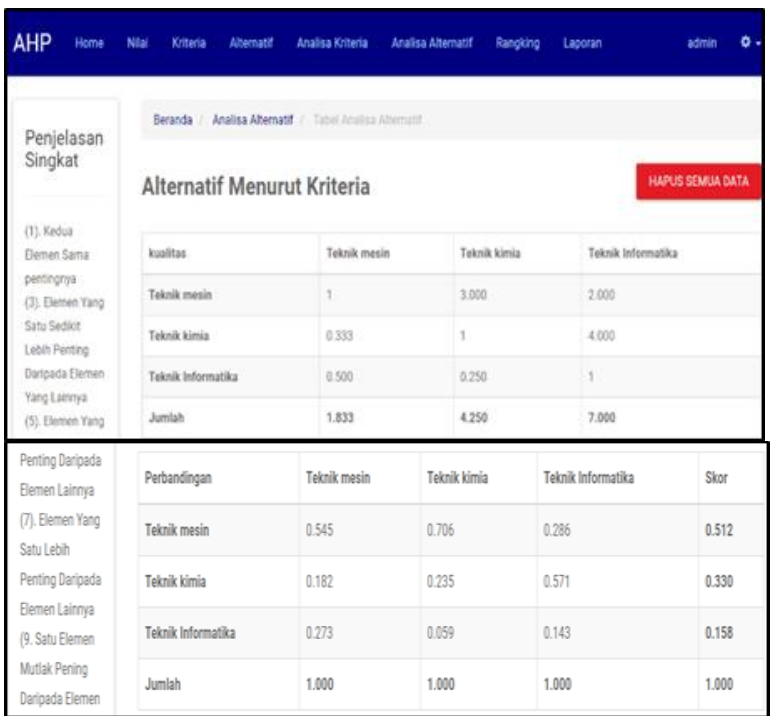

Gambar 21. Halaman Perbandingan Berpasangan Alternatif Menurut Kriteria

\subsection{Halaman Analisa Alternatif (Biaya)}

Gambar 22 menjelaskan tentang analisa data alternatif untuk mengetahui hasil perhitungan perbandingan berpasangan dari setiap proses perhitungan kriteria biaya dan alternatif.

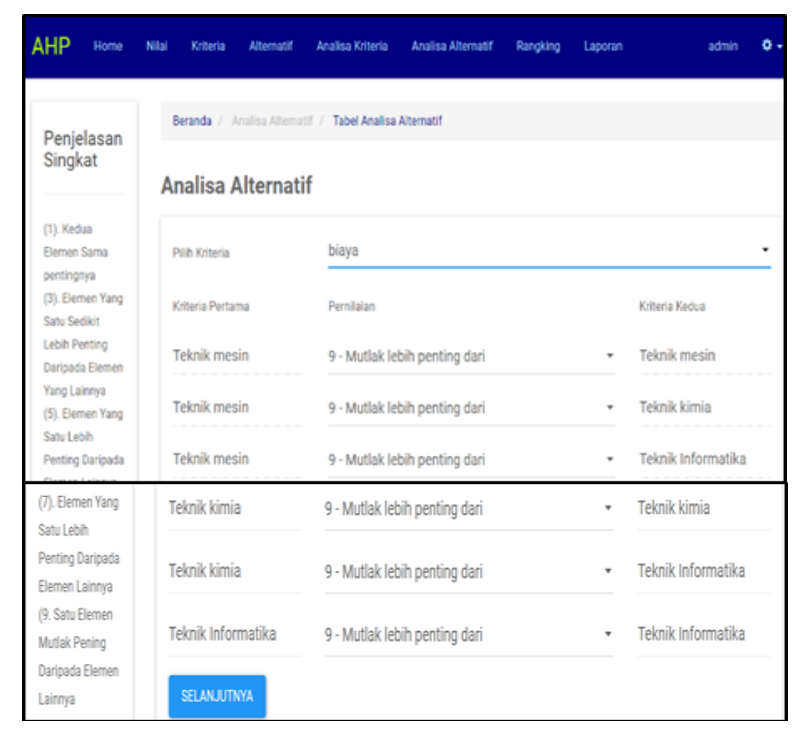

Gambar 22. Halaman Analisa Alternatif Kriteria Biaya

Selanjutnya akan menginput data analisa alternatif dalam kriteria biaya untuk menentukan perhitungan perbandingan berpasangan.

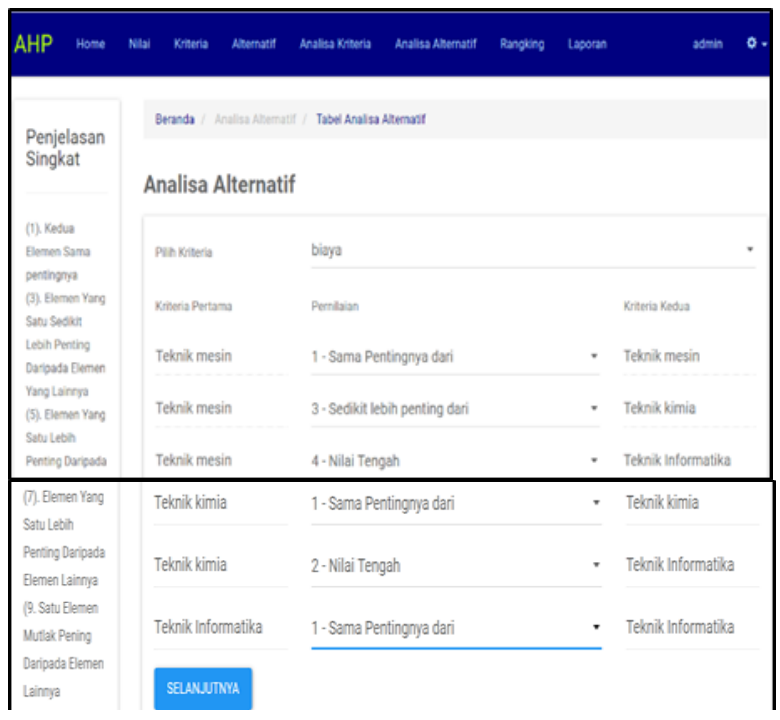

Gambar 23. Halaman Analisa Alternatif Kriteria Biaya Lanjutan

Maka selanjutnya akan muncul hasil perhitungan perbandingan berpasangan alternatif menurut kriteria yang sudah dipilih dalam menentukan hasil perangkingan progam studi.

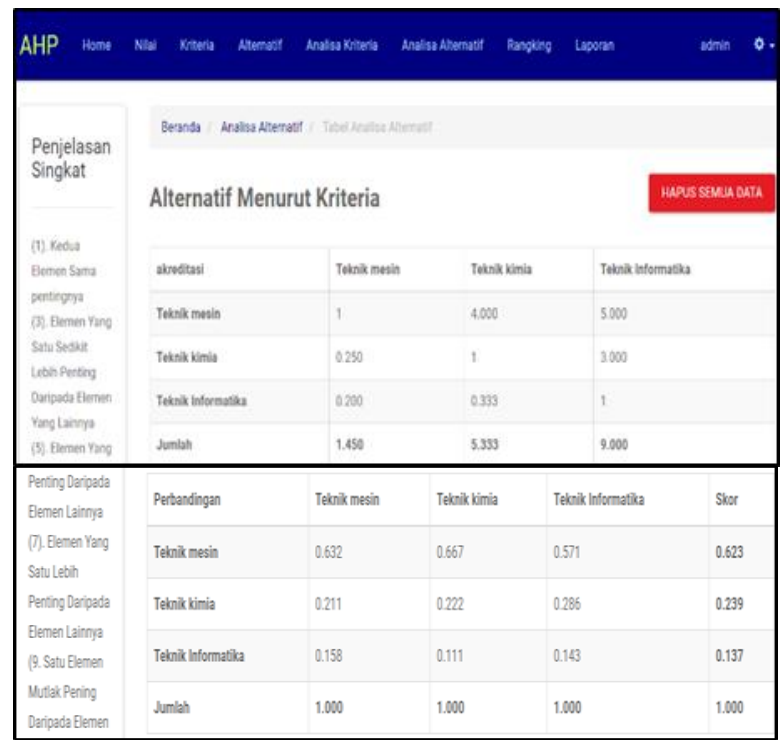

Gambar 24. Halaman Analisa Alternatif Lanjutan

5.10 Halaman Analisa Alternatif (Akreditasi) Gambar 25 menjelaskan tentang analisa data alternatif untuk mengetahui hasil perhitungan perbandingan berpasangan dari setiap proses perhitungan kriteria akreditasi dan alternatif. 


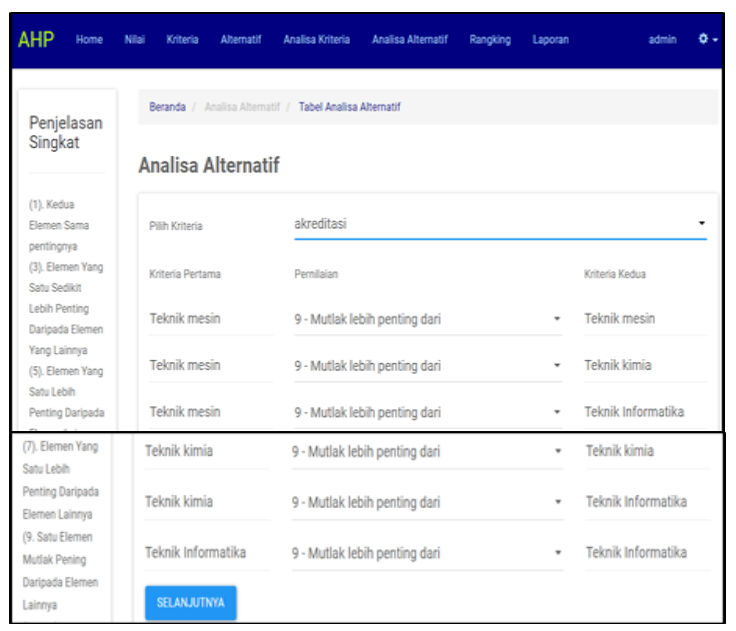

Gambar 25. Halaman Analisa Alternatif Kriteria Akreditasi

Selanjutnya akan menginput nilai yang sesuai dengan kebutuhan perhitungan.

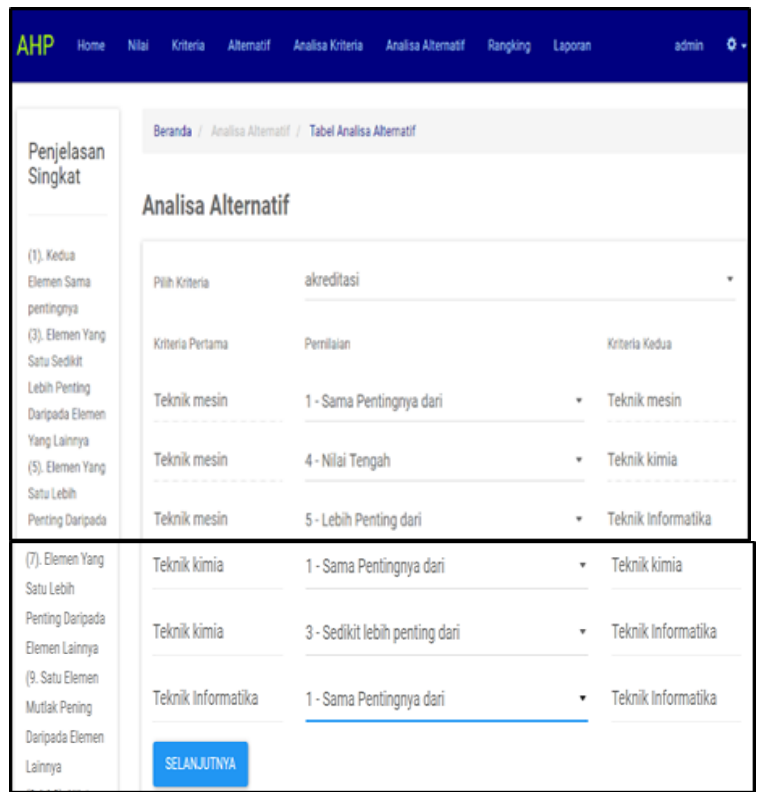

Gambar 26. Halaman Analisa Alternatif Kriteria Akreditasi Lanjutan

Maka selanjutnya akan muncul hasil perhitungan perbandingan berpasangan dalam menentunkan hasil perangkingan progam studi.

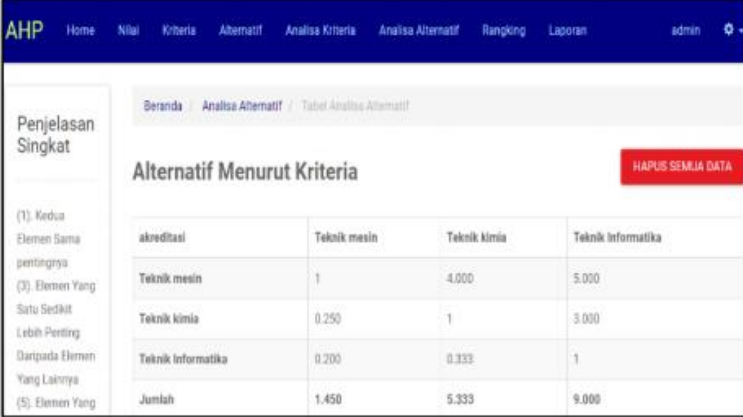

Gambar 27. Halaman Perbandingan Berpasangan Alternatif Menurut Kriteria

\subsection{Halaman Data Perangkingan}

Gambar 28 menjelaskan tentang hasil perhitungan perbandingan berpasangan kriteria dan alternatif untuk menentukan hasil perangkingan pada pemilihan program studi.

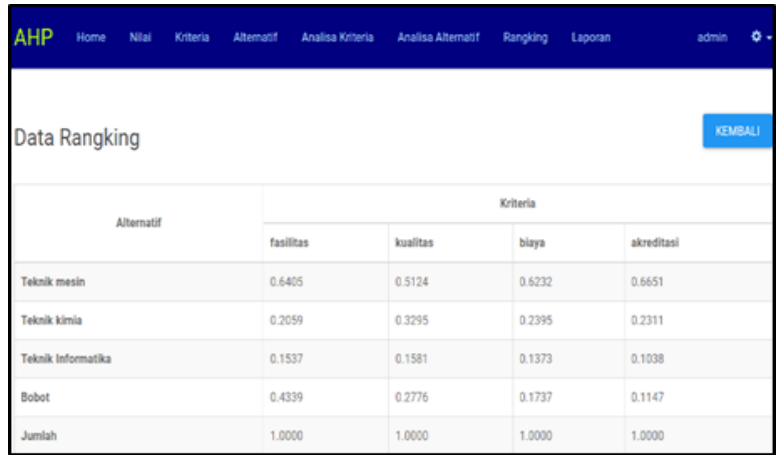

Gambar 28. Halaman Data Perankingan

\subsection{Halaman Hasil Perangkingan}

Gambar 29 menjelaskan tentang relasi dari data rangking yang berupa perhitungan perbandingan berpasangan dan menentukan hasil bobot atau skor dari kriteria fasilitas, kualitas, biaya, akreditasi dan alternatif.

\begin{tabular}{|c|c|c|c|c|c|}
\hline $\begin{array}{l}\text { Perting Daripoda } \\
\text { Elemen Lainya }\end{array}$ & Perbandingan & Teknik mesin & Teknik kimia & Teknik Informatika & Skor \\
\hline $\begin{array}{l}\text { (7). Elemen Yang } \\
\text { Satu Lebin }\end{array}$ & Teknikmesin & 0.690 & 0.750 & 0.556 & 0.665 \\
\hline Penting Daripada & Teknik kimia & 0.172 & 0.188 & 0.333 & 0.231 \\
\hline $\begin{array}{l}\text { Elemen Laimya } \\
\text { (9. Satu Elemen }\end{array}$ & Teknik Informatika & 0.138 & 0.062 & 0.111 & 0.104 \\
\hline $\begin{array}{l}\text { Mutak Pening } \\
\text { Dariodada Elemen }\end{array}$ & Jumlah & 1.000 & 1.000 & 1.000 & 1.000 \\
\hline
\end{tabular}

Gambar 29. Halaman Hasil Perangkingan

\subsection{Halaman Laporan Cetak}

Gambar 30 menjelaskan tentang laporan hasil perhitungan dari perhitungan perbandingan 
berpasangan dan perhitungan bobot/ skor maka akan dicetak hasil dari data perangkingan tersebut.

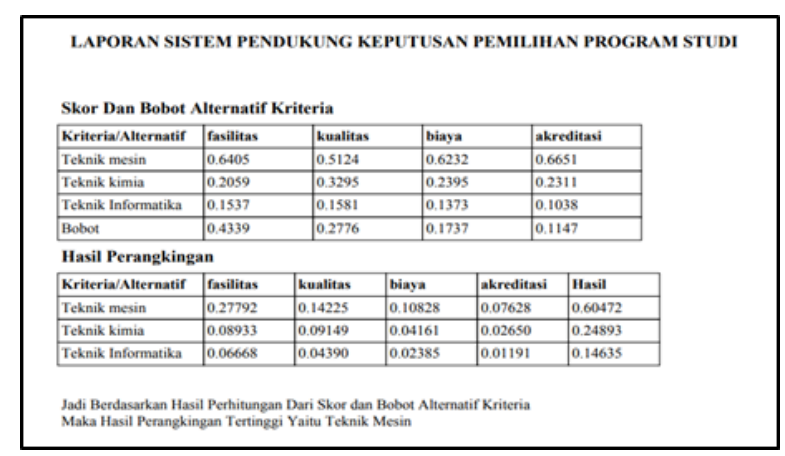

Gambar 30. Halaman Laporan Cetak

\subsection{Halaman Hasil Data Kriteria}

Gambar 31 menjelaskan tentang hasil perhitungan data kriteria untuk menentukan bobot/skor dalam kriteria.

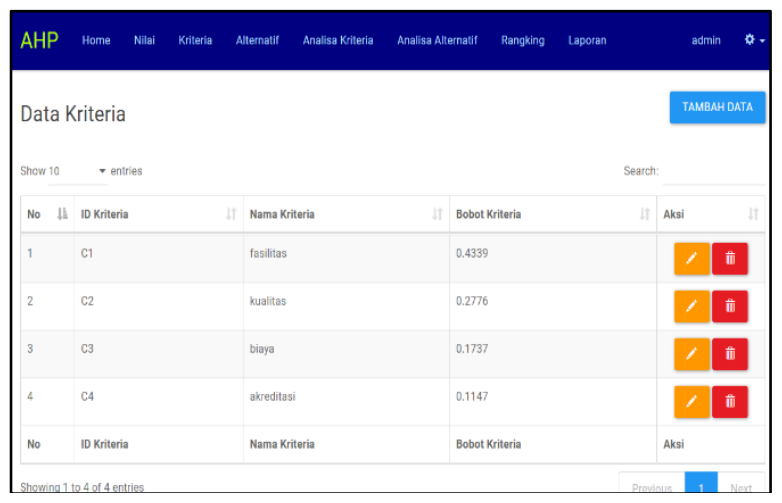

Gambar 31. Halaman Hasil Data Kriteria

\subsection{Halaman Hasil Data Alternatif}

Gambar 32 menjelaskan tentang hasil perhitungan data alternatif untuk menentukan bobot/skor dalam alternatif.

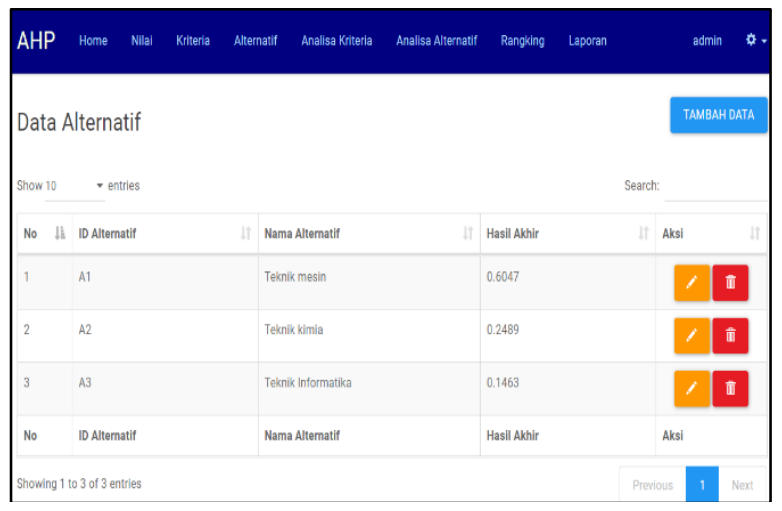

Gambar 32. Halaman Hasil Data Alternatif

\section{DAFTAR PUSTAKA}

Budilaksono, Sularso, dkk, 2016, Sistem Pendukung Keputusan Pemilihan Perguruan Tinggi Swasta Program Studi Teknik Informatika Di Provinsi DKI Jakarta Dengan Metode AHP dan Promethee, (Seminar Nasional Teknologi Informasi dan Multimedia 2016), STMIK AMIKOM, hal 7-12.

Darmanto, Eko, dkk, 2014, Penerapan Metode AHP (Analytical Hierarchy Process) Untuk Menentukan Kualitas Gula Tumbu, (Jurnal SIMETRIS), Kudus, 7582.

Kusrini, 2007 (Konsep Dan Aplikasi Sistem Pendukung Keputusan), Andi, Yogyakarta.

Na'am, Jufriadif, 2017, Sebuah Tinjauan Penggunaan Metode Analytic Hierarchy Process (AHP) dalam Sistem Penunjang Keputusan (SPK) pada Jurnal Berbahasa Indonesia , (MEDIASISFO), Padang, Vol.11 No.2.

Saaty, T.L. (2008) 'Decision making with the analytic hierarchy process', (Int. J. Services Sciences), Vol. 1, No. 1, hal 8398. 